\title{
The Effect of Profit Sharing Financing, TPF and Capital on Net Profit through Revenue Sharing on Buses
}

\author{
Sugiantor ${ }^{1}$, Yenni Samri Juliati Nst² ${ }^{2}$, Winda Anriani Siregar ${ }^{3}$ \\ ${ }^{1,2}$ Universitas Islam Negeri Sumatera Utara, Indonesia \\ ${ }^{3}$ Postgraduate Program in Universitas Islam Negeri Sumatera Utara, Indonesia \\ sugianto@uinsu.ac.id,yenni.samri@uinsu.ac.id,windaandrianisrg@gmail.com
}

\begin{abstract}
This study aims to determine how much influence the financing for the results, DPK and capital on net income mediated by revenue sharing. The sample used in this study is data 10 BUS in annual form from 2014 to 2019, and the approach used uses a quantitative approach. This study uses 60 samples that are processed using panel data regression analysis method using the views 9 application. The results of the analysis show that this study produces a coefficient of determination (R-square) in structural model I, which is $96.1 \%$ of the variable for profit sharing, TPF, and capital affects profit sharing income in Islamic commercial banks, while $3.9 \%$ is explained by other variables. The result of the coefficient of determination ( $R$-square) model II is $22.6 \%$, the variable of profit sharing, TPF, capital and revenue sharing affects the net profit in Islamic commercial banks, while $77.4 \%$ is influenced by other variables. This study shows that the financing for the results, TPF, capital and revenue sharing have a simultaneous effect on net income with a significance level of $0.001<0.05$. From the results of the indirect effect significance test, it was found that there was no significant indirect effect of the profit sharing variable, TPF and capital on net income through revenue sharing as an intervening variable in Islamic commercial banks. Capital and profit sharing income affect net income in Islamic commercial banks while $77.4 \%$ is influenced by other variables.
\end{abstract}

Keywords

profit sharing financing, DPK capital; revenue sharing and net profit

\section{Introduction}

The development of Islamic banking in Indonesia has progressed significantly, which can be seen from the publication of Bank Indonesia (BI). This also further supports the commitment of BI in the development of Islamic banks (Rahmati, 2018). There are 14 Islamic Commercial Banks and 20 Islamic business units with total assets of 5,143 trillion. The increase in the number of Islamic banks in Indonesia shows that public trust in Islamic banks in managing customer funds is increasing. Moreover, Bank Indonesia has launched the National Non-Cash Movement (GNNT) since 2014 which aims to bring Indonesia into the era of people without money or Cashless Society (Dianto, 2020). This also proves that Islamic banks contribute greatly to the economic activities of the community according to Islamic sharia, providing easy and fintech-based services according to Islamic sharia.

The general objective of Islamic banks is to accelerate the economic growth of the community by conducting commercial banking activities, finance, investing in accordance with sharia to make a profit. To make a profit, Islamic banks carry out their business activities by collecting (funding) and channeling (financing) funds to people who are short of funds (deficit). One of the funds collected by the bank comes from the community called 
third party funds (DPK) and capital becomes a source of funds for the bank to carry out its operational activities. The DPK collected will be channeled back in the form of financing with the aim of making a profit. DPK is collected in the form of savings, current accounts and time deposits.

According to Muhammad (2004) the source of funds for Islamic banks other than DPK is paid-in capital. Capital is a fund that is given by the owner or shareholder. Capital can be channeled for productive things, namely financing. The more sources of funds the bank has, the more financing is channeled, the bank will get revenue and will increase the bank's net profit.

Following is table 1, especially 4 (four) Islamic Commercial Banks, data on profit sharing, TPF, capital, revenue sharing and net income fluctuated from 2014 to 2019.

Table 1. Amount of Data for Profit Sharing Financing, TPF, Capital, Revenue Sharing, and Net Profit 4 Islamic Commercial Banks

(In Millions)

\begin{tabular}{|l|l|c|c|c|c|c|}
\hline Bank & Year & $\begin{array}{c}\text { Pemb. } \\
\text { Basil }\end{array}$ & DPK & Capital & $\begin{array}{c}\text { Pend. } \\
\text { Basil }\end{array}$ & $\begin{array}{c}\text { Net } \\
\text { profit }\end{array}$ \\
\hline BVS & 2014 & 596,185 & $1,116,830$ & 160,000 & 53,325 & $(19,022)$ \\
\hline & 2015 & 712,541 & $1,083,256$ & 160,000 & 76,496 & $(24,001)$ \\
\hline & 2016 & 949,606 & $1,104,681$ & 210,000 & 69,403 & $(18,478)$ \\
\hline & 2017 & 932,212 & $1,511,159$ & 270,000 & 96,027 & 4,593 \\
\hline & 2018 & 987,159 & $1,491,442$ & 310,000 & 97,781 & 4,974 \\
\hline & 2019 & $1,009,609$ & $1,506,190$ & 360,000 & 92,866 & 913 \\
\hline BJBS & 2014 & $1,292,787$ & $4,253,140$ & 609,000 & 150,650 & 21,702 \\
\hline & 2015 & $1,112,650$ & $4,229,199$ & 609,000 & 135,615 & 14,913 \\
\hline & 2016 & $1,054,188$ & $5,453,390$ & $1,009,000$ & 105,674 & $(414,714)$ \\
\hline & 2017 & 975,965 & $5,977,834$ & $1,259,000$ & 93,996 & $(383,428)$ \\
\hline & 2018 & $1,258,276$ & $4,805,401$ & $1,259,000$ & 93,634 & 16,897 \\
\hline & 2019 & $1,719,093$ & $5,362,739$ & $1,510,890$ & 169,322 & 15,399 \\
\hline & 2014 & $1,495,067$ & $3,523,037$ & 650,370 & 170,222 & 8,498 \\
\hline & 2015 & $2,100,583$ & $4,756,303$ & 750,370 & 206,803 & 22,778 \\
\hline & 2016 & $2,527,173$ & $5,442,608$ & 850,370 & 294,598 & 32,710 \\
\hline & 2017 & $2,753,373$ & $5,498,424$ & $1,050,370$ & 289,523 & 1,648 \\
\hline & 2018 & $2,698,851$ & $4,543,665$ & $1,050,370$ & 283,331 & 2,245 \\
\hline & 2019 & $3,098,087$ & $4,454,175$ & $1,050,370$ & 263,402 & 1,729 \\
\hline BCAS & 2014 & $1,007,345$ & $2,041,498$ & 596,300 & 88,198 & 12,949 \\
\hline & 2015 & $1,348,175$ & $3,255,154$ & 996,300 & 145,410 & 23,437 \\
\hline & 2016 & $1,646,643$ & $3,843,273$ & 996,300 & 153,010 & 36,816 \\
\hline & 2017 & $2,059,992$ & $4,736,403$ & 996,300 & 42,892 & 47,860 \\
\hline & 2018 & $2,674,887$ & $5,506,112$ & 996,300 & 51,115 & 58,367 \\
\hline & 2019 & $3,500,456$ & $4,878,717$ & $1,996,300$ & 286,610 & 67,194 \\
\hline
\end{tabular}

Source: www.ojk.co.id

Based on table 1.1 above, it provides an overview of the specific developments of 4 Islamic Commercial Banks in Indonesia. It can be seen that the financing for the results, DPK, capital, net profit, and revenue sharing has increased and decreased or fluctuated. The highest mudharabah financing occurred at Bank Syariah Bukopin (BSB) in 2017 amounting to Rp. 2,753,373 and the lowest financing at Bank Victoria Syariah (BVS) in 2014 amounting to Rp. 596,185. The highest DPK at Bank Jabar Banten Syariah (BJBS) in 2017 amounted to 
Rp. 5,977,834 and the lowest TPF in BVS in Rp. 1,083,256. The highest capital at Bank Central Asia Sariah (BCAS) in 2019 is Rp. 1,996,300 and the lowest capital in 2014 BCAS. The highest revenue sharing in BSB in 2016 was Rp. 294,598 and the lowest profit sharing income in BCAS 2018 amounting to Rp. 51,115. The highest net profit in BCAS in 2019 was Rp. 67,194 and the lowest was in the 2016 BJBS $(414,714)$

With an increase in the net profit of Islamic banks from the financing offered by Islamic banks, it proves that the public believes in investing their funds in Islamic banks. The purpose of this study was to determine the direct effect of profit sharing financing, TPF, and capital on net income and to determine the direct and indirect effect of profit sharing financing, TPF, capital on intervening net income or mediating revenue sharing. Based on table 1.1, the occurrence of fluctuations in production sharing financing, TPF, capital, revenue sharing and net income is interesting to do.

\section{Review of Literature}

\subsection{Profit}

The general objective of Islamic banks is to encourage and accelerate the economic growth of the community to carry out banking, commercial, financial and investment activities in accordance with Islamic sharia. The main objective of conventional banks is to achieve the maximum possible profit or profit. The profit referred to in this research is net income. Net income is the difference in income after deducting expenses and is the increase in capital for the activities of a bank or company. Profit is an indicator to measure the performance of a bank or company. Net income is presented in the financial statements in the income statement by juxtaposing income and expenses. To get profit, the bank must carry out its operational activities. The factors that affect the net profit of the bank are the activities of the bank to collect funds from the public, namely third party funds (TPF) and their own capital. TPF and capital are the main sources of bank funds to carry out their operational activities. Deposits and capital will be channeled by the bank back to people who lack funds in the form of profit sharing (mudharabah and musyarakah) financing, sale and purchase contract financing (al bai ', lease contract financing (ijarah) and in the form of other services such as administrative costs (Yani, 2019).

\subsection{Revenue Sharing}

The income generated from the financing agreement, after deducting operating costs, must be shared between the bank and the funding customers, namely investors, savers, and shareholders according to the profit sharing ratio agreed upon at the beginning of the contract. Income is the income received by the bank in cash from the results of investment in productive assets. The productive assets channeled by Islamic banks will generate income from sale and purchase contracts to generate margins, lease or ijarah contracts to generate rental income, and production sharing financing to generate revenue sharing. Profit sharing income is the sharing of business results between the owner of the capital and the customer according to the portion of the capital of each party and the ratio agreed upon at the beginning of the contract. Profit sharing income is obtained from two mudharabah and musyarakah financing contracts. Profit sharing income obtained by the bank will affect the increase in the bank's net profit. 


\subsection{Profit Sharing Financing}

According to Kasmir, financing is the provision of funds by Islamic banks based on an agreement or agreement between the bank and the customer which requires the financed party to return the funds after a certain period of time in exchange for profit sharing. According to Ismail, from the financing side, if the customer gets a large income, then the Islamic bank and the customer will also get a large income. If the income received by Islamic banks and customers is small, the income earned by Islamic banks is also small. Profit sharing financing is the financing of the mudharabah and musyarakah profit sharing contracts. This means that if the mudharabah financing channeled by the bank is high, the Islamic bank and its customers will also get high revenue sharing. Conversely, if Islamic banks channel a little mudharabah financing, then the Islamic banks and customers will get a low profit sharing as well. Profit sharing income obtained by Islamic banks will have an effect on increasing bank profits.

\subsection{Third Party Fund (DPK)}

DPK is one of the sources of bank funds collected from the public in the form of savings, current accounts and time deposits. According to Law 21 of 2008, DPK is a deposit of funds entrusted by a customer to a sharia bank with a wadi'ah contract and other contracts that do not conflict with Islamic law in the form of savings, time deposits and demand deposits. The collected deposits will be channeled by the bank in the form of financing in order to achieve the maximum possible profitability and minimum risk and to keep the bank's liquidity safe. According to Ikit, the more funds collected from the public, the higher the amount of funds channeled in the form of financing. From TPF that is distributed in the form of financing, the bank will get income and it will affect the bank's profit (Ikit, 2018):

\subsection{Capital}

Capital is a fund given to or given by the owner as proof of his participation in the activities of a sharia bank. The owners will receive the results of operations in the form of dividends. Capital funds can be used for productive things in the form of financing and the owner of the capital will receive income in the form of dividends. Capital serves as a buffer and absorber of bank failures or losses and protects the interests of ownership account holders.

\section{Research Methods}

This research is a quantitative research. This study was analyzed using path analysis. The data used in this study are secondary data from the financial statements of 10 Islamic Commercial Banks in Indonesia through the websitewww.ojk.co.idfrom 2014 to 2019. The population of this study is Islamic Commercial Banks consisting of 14 Islamic banks. The sample of this research that was selected there were 10 Islamic Commercial Banks in Indonesia.

\section{Discussion}

\subsection{Model Selection Test}

The model selection test is choosing the most appropriate method for this study using three approaches, namely the commen effect, fixed effect and random effect. To maintain the correct method of the three approaches, the chow test, hausman test and Lagrange multiplier test were used. After the chow test and yield test have not found the most appropriate method, so to determine the most appropriate method is used the Lagrange multiplier test. The lagrange multiplier test results are as follows: 
Table 2. Lagrange Multiplier Model 1 Test Results

\begin{tabular}{cccc}
\hline & $\begin{array}{c}\text { Cross } \\
\text { section }\end{array}$ & $\begin{array}{c}\text { Hypothesis } \\
\text { Time Test }\end{array}$ & Both \\
\hline $\begin{array}{c}\text { Breusch } \\
\text { Pagan }\end{array}$ & 0.580568 & 0.654936 & 1.235504 \\
\hline Probability & 0.4461 & 0.4184 & 0.2663 \\
\hline
\end{tabular}

Source: Output Eviews 9, data processed for June 2020

The results of the lagrange multiplier model I test show that the probability value is greater than 0.05 , namely $0.4461>0.05$, so the right model for model I is the random effect model.

Table 3. Lagrange Multiplier Test Results

\begin{tabular}{cccc}
\hline & Cross Section & Hypothesis Time Test & Both \\
\hline Breusch Pagan & 3.050836 & 0.111781 & 3.16217 \\
\hline Probability & $(0.0807)$ & $(0.7381)$ & $(0.0753)$ \\
\hline
\end{tabular}

Source: Output Eviews 9, data processed in June 2020

The result of the Lagrange multiplier model II test shows that the probability value is greater than 0.05 , namely $0.0807>0.05$, so the appropriate model for model II is the random effect model. Based on the results of the Lagrange multiplier test model I and model II, the appropriate method for this study is the random effect model.

\subsection{Classic Assumption Test}

a. Normality Test

The results of the normality test in model I can be seen in Figure 1 below:

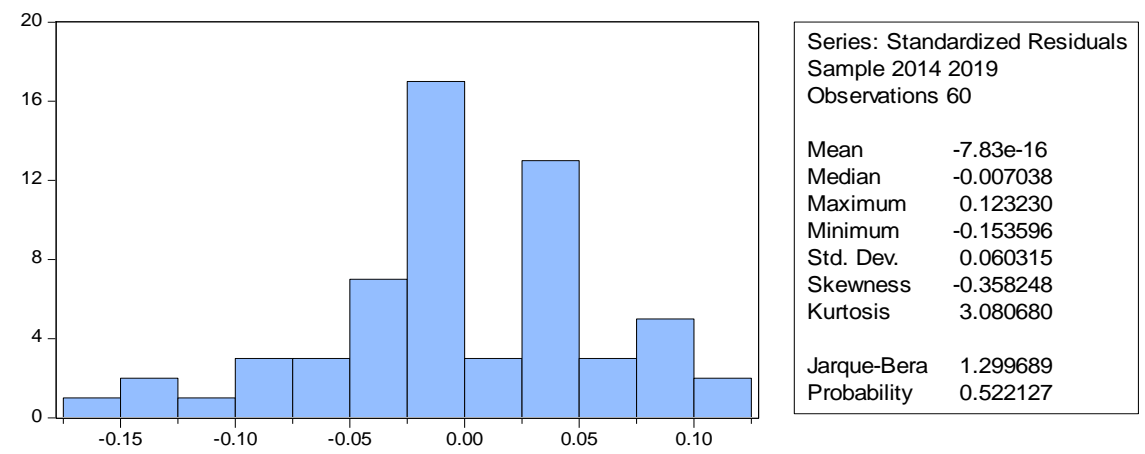

Figure 1. Model I Normality Test Results

Source: Output eviews 9, data processed in June 2020

The results of the normality test in model I are declared normal because the probability value is greater than 0.05 , namely $0.522>0.05$. Furthermore, the model II normality test can be seen in Figure 2 below. 


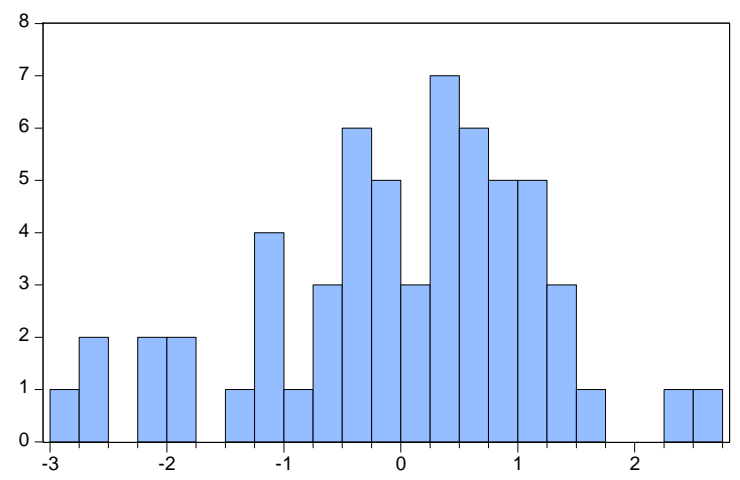

\begin{tabular}{|lc}
\hline \multicolumn{2}{l}{ Series: Standardized Residuals } \\
Sample 2014 2019 \\
Observations 59 \\
Mean & $-5.91 \mathrm{e}-15$ \\
Median & 0.137727 \\
Maximum & 2.704115 \\
Minimum & -2.768962 \\
Std. Dev. & 1.197137 \\
Skewness & -0.370648 \\
Kurtosis & 2.925561 \\
& \\
Jarque-Bera & 1.364523 \\
Probability & 0.505473 \\
\hline
\end{tabular}

Figure 2. Model II Normality Test Results

Source: Output eviews 9, data processed in June 2020

The results of the normality test in model II are declared normal because the probability value is greater than 0.05 , namely $0.505>0.05$.

\section{b. Multicollinearity Test}

Table 4. Multicollinearity Test Results Model I

\begin{tabular}{|c|c|c|c|c|c|}
\hline & & $\begin{array}{l}\text { Profit } \\
\text { Financing }\end{array}$ & Sharing & DPK & Capital \\
\hline $\begin{array}{l}\text { Profit } \\
\text { Financing }\end{array}$ & Sharing & 1,000000 & & 0.771472 & 0.217471 \\
\hline DPK & & 0.771472 & & 1,000000 & 0.243858 \\
\hline Capital & & 0.217471 & & 0.243858 & 1,000000 \\
\hline
\end{tabular}

Source: Output eviews 9, data processed in June 2020

Based on table 4 above, it shows that there is no independent variable data (profit sharing, DPK, and capital) which has a correlation coefficient above 0.80 so that it is concluded that it is free from multicollinearity problems.

The results of the model II multicollinearity test can be seen in table 5 below:

Table 5. Multicollinearity Test Results Model II

\begin{tabular}{c|c|c|c|c}
\hline & $\begin{array}{c}\text { Profit } \\
\text { Sharing } \\
\text { Financing }\end{array}$ & DPK & Capital & $\begin{array}{c}\text { Revenue } \\
\text { Sharing }\end{array}$ \\
\hline $\begin{array}{c}\text { Profit Sharing } \\
\text { Financing }\end{array}$ & 1,000000 & 0.772814 & 0.217623 & 0.993944 \\
\hline DPK & 0.772814 & 1,000000 & 0.239508 & 0.757297 \\
\hline Capital & 0.217623 & 0.239508 & 1,000000 & 0.179518 \\
\hline $\begin{array}{c}\text { Revenue } \\
\text { Sharing }\end{array}$ & 0.993944 & 0.757297 & 0.179518 & 1,000000 \\
\hline
\end{tabular}

Source: Output Eviews 9, data processed in June 2019

Based on table 5 above, it shows that there is no independent variable data (revenue sharing, DPK, capital and revenue sharing) which has a correlation coefficient above 0.80 so that it is concluded that it is free from multicollinearity problems. 
Table 6. Autocorrelation Test Results Model I

\begin{tabular}{ll}
\hline Variable & Probability \\
\hline Profit Sharing Financing & 0.5767 \\
\hline DPK & 0.8485 \\
\hline Capital & 0.3683 \\
\hline
\end{tabular}

Source: Output eviews 9, data processed in June 2020

Based on table 6 above, it can be concluded that there is no autocorrelation problem. All probability values of each independent variable (revenue sharing, TPF, and capital) are greater than 0.05 . The results of the model II autocorrelation test can be explained in table 1.7 below:

Table 7. Autocorrelation Test Results Model I

\begin{tabular}{ll}
\hline Test & Statistics \\
\hline Durbin-Watson & 1,738225 \\
\hline
\end{tabular}

Source: Output eviews 9, data processed in June 2020

Based on table 7 above, it can be concluded that there is no autocorrelation problem. The DW value is 1.738225 which in conclusion the DW value is between -2 and +2 .

The results of the model II autocorrelation test can be explained in table 8 below:

Table 8. Autocorrelation Test Results Model II

\begin{tabular}{ll}
\hline Test & Statistics \\
\hline Durbin-Watson & 1.348524 \\
\hline Source: Output eviews 9, data processed & in June 2020
\end{tabular}

Source: Output eviews 9, data processed in June 2020

Based on table 8 above, it can be concluded that there is no autocorrelation problem. The DW value is 1.348225 which in conclusion the DW value is between -2 and +2 .

\subsection{Multiple Regression Analysis Statistical Test \\ a. Coefficient of Determination (R2)}

The R2 value in model $\mathrm{I}$ is 0.961 or $96.1 \%$. This means that the influence of independent variables (profit sharing financing, TPF, and capital on the dependent variable (net income) is $96.1 \%$, while the remaining $3.9 \%$ is influenced by other variables not included in this study.

The R2 value in model II is 0.226 or $22.6 \%$. This means that the influence of the independent variables (financing for results, DPK, capital, and revenue sharing) on the dependent variable (net income) is $22.6 \%$, while the remaining $77.4 \%$ is influenced by other factors not included in this study.

\section{b. F statistical test (Simultaneous)}

Table 9. F Test Results (Simultaneous) Model I

\begin{tabular}{l|l}
\hline F-Statistics & 479,6109 \\
\hline Prob (F-Statistics) & 0.0000 \\
\hline
\end{tabular}

Source: Output eviews 9, data processed in June 2020 
Based on table 9 above, the F-table value is 2.77. The value of F-Statistics $>$ F-table is $479.6109>2.77$ and the probability value is $<0.05$, namely $0.0000<0.05$ so that it can be concluded that the independent variables (profit sharing, TPF, and capital) have a simultaneous or jointly significant effect on the dependent variable (profit clean).

The F (simultaneous) model II statistical test can be seen in table 10 below:

Table 10. F Test Results (Simultaneous) Model I

\begin{tabular}{l|l}
\hline F-Statistics & 5.2510 \\
\hline Prob (F-Statistics) & 0.0012 \\
\hline
\end{tabular}

Source: Output eviews 9, data processed in June 2020

Based on table 10 above, the F-table value is 2.38. The value of F-Statistic > F-table is $5.2510>2.38$ and the probability value $<0.05$ is $0.0002<0.05$ so that it can be concluded that the independent variables (profit sharing financing, TPF, capital and revenue sharing) have a joint and significant effect on the dependent variable ( net profit).

c. Partial Test (Test t)

Table 11. Partial Test Results (t) Model I

\begin{tabular}{lll}
\hline Variable & t-Statistics & Probability \\
\hline Profit Sharing Financing & 17.25726 & 0.0000 \\
\hline DPK & -0.045141 & 0.9642 \\
\hline Capital & -2.699610 & 0.0092 \\
\hline
\end{tabular}

Source: Output Eviews 9, data processed in June 2020

Based on table 11 above, profit sharing financing has a partial and significant effect on revenue sharing where $\mathrm{t}>\mathrm{t}$ table is $17.2572>1.67252$ and the probability value $<0.05$ is $0.0000<0.05$. The TPF variable has no partial effect on the revenue sharing variable where $t$ count $<\mathrm{t}$ table is $-0.045141<1.6725$ and the probability value $>0.05$ is $0.9642>0.05$. The variable capital has a negative effect on revenue sharing. The value of $t$ count $>t$ table is $2699610>1.6725$ and the probability value $<0.05$ is $0.0092<0.05$.

The partial test results ( $\mathrm{t}$ ) of model II can be seen in table 1.12 below:

Table 12. Partial Test Results (t) Model II

\begin{tabular}{l|l|l}
\hline Variable & t-Statistics & Probability \\
\hline Profit Sharing Financing & 1.071719 & 0.2886 \\
\hline DPK & 3.421066 & 0.0012 \\
\hline Capital & -1.384739 & 0.1718 \\
\hline Revenue Sharing & -1.101404 & 0.2756 \\
\hline
\end{tabular}

Source: Output eviews 9, data processed in June 2020

Based on table 12 above, the profit sharing variable has no effect on net income where $t$ count $<\mathrm{t}$ table is $1.071719<1.67303$ and the probability value $>0.05$ is $0.2886>0.05$. TPF has an effect on net income where $t$ count $>t$ table is 3.421006> 1.67303 and the probability value $<0.05$ is $0.0012<0.05$. The capital variable has no effect on the net income variable where $t$ count $<\mathrm{t}$ table is $-1.384739<1.67303$ and the probability value $>0.05$ is $0.1718>0.05$. Profit sharing variable has no effect on net income where $t$ count $<t$ table is $-1.101404<0.2756$ and the probability value $>0.05$ is $0.2756>0.05$. 


\subsection{Direct Influence}

Based on the results of the path analysis regression test from model I and model II, the results of the direct effect test can be seen in the coefficient value of table 13.

Table 13. Direct Effect Test Results

\begin{tabular}{l|l|l|l}
\hline Direct Effect & Coefficient & Probability & \\
\hline $\begin{array}{l}\text { Pemb. BH against } \\
\text { Pend.BH }\end{array}$ & 0.085 & 0.000 & Significant \\
\hline $\begin{array}{l}\text { DPK against Pendants. } \\
\text { BH }\end{array}$ & $-8,170$ & 0.964 & $\begin{array}{l}\text { Not } \\
\text { significant }\end{array}$ \\
\hline Capital against Pend.BH & -0.053 & 0.009 & Significant \\
\hline Pemb.BH against LB & 1,152 & 0.288 & $\begin{array}{l}\text { Not } \\
\text { significant }\end{array}$ \\
\hline DPK against LB & 0.885 & 0.001 & Significant \\
\hline Capital against LB & -0.157 & 0.171 & $\begin{array}{l}\text { Not } \\
\text { significant }\end{array}$ \\
\hline Pend.BH against LB & $-1,181$ & 0.275 & $\begin{array}{l}\text { Not } \\
\text { significant }\end{array}$ \\
\hline
\end{tabular}

\subsection{Indirect Influence}

The mediating variable (intervening) in this study is revenue sharing. To calculate the indirect effect, the Sobel formula is used. This sobel test is used to calculate the effect of sharing financing, TPF, and capital on net income through revenue sharing. The calculation of the indirect effect can be seen below:

1. Calculation of Path I

Sat $=\sqrt{b^{2} s a^{2}+a^{2} s b^{2}+s a^{2} s b^{2}}$

$$
\begin{aligned}
& =\sqrt{\left.(-1.181)^{2}(0.004)^{2}+(0.085)^{2}(1.072)^{2}+(0.004)^{2} 1.072\right)^{2}} \\
& =\sqrt{(1.394)(1.600)+(0.007)(1.149)+(1.600)(1.149)} \\
& =\sqrt{2.230+0.008+1.838} \\
& \quad=\sqrt{4.0764} \\
& =2.018
\end{aligned}
$$

2. Pathway II calculations

$$
\begin{aligned}
& \text { Scd }=\sqrt{d^{2} s c^{2}+c^{2} s d^{2}+s c^{2} s d^{2}} \\
& \begin{aligned}
= & \sqrt{(-1.181)^{2}(0.001)^{2}+(-8.170)^{2}(1.072)^{2}+(0.001)^{2}(1.072)^{2}} \\
= & \sqrt{(1.394)(1.000)+(66.748)(1.149)+(1.000)(1.149)} \\
& =\sqrt{1.394+76.93+2.149} \\
& =\sqrt{80.236} \\
& =8.957
\end{aligned}
\end{aligned}
$$

3. Calculation of Path III

$$
\begin{aligned}
& \text { Sef }=\sqrt{f^{2} s e^{2}+e^{2} s f^{2}+s e^{2} s f^{2}} \\
& =\sqrt{(-1.181)^{2}(0.019)^{2}+(-0.053)^{2}(1.072)^{2}+(0.019)^{2}(1.072)^{2}} \\
& \quad=\sqrt{(1.394)(0.001)+(0.003)(1.149)+(0.001)(1.149)} \\
& =\sqrt{0.001+0.003+0.001} \\
& =0.070
\end{aligned}
$$


To test the significance of the indirect effect, we need to calculate the $t$ value of the coefficients ab, cd, and ef with the following formula:

$$
\begin{aligned}
& \text { 1. Path I } \\
& \mathrm{t}=\frac{a b}{s a b}=\frac{0.085 x(-1.181)}{2.018} \\
& =-0.049 \\
& \mathrm{t}=\frac{\text { cd }}{\text { scd }}=\frac{(-8.170) \times(-1.181)}{8.957} \\
& =1,077
\end{aligned}
$$

3. Path III

$$
\begin{aligned}
& \mathrm{t}=\frac{\text { ef }}{\text { sef }}=\frac{-0.053 x-1.181}{0.070} \\
& =0.88
\end{aligned}
$$

Table 14. Indirect Effect Test Results

\begin{tabular}{l|l|l|l}
\hline Indirect Effect & t count & t table & Conclusion \\
\hline $\begin{array}{l}\text { Pem.BH against LB } \\
\text { through Pend. BH }\end{array}$ & -0.049 & 1.67303 & $\begin{array}{l}\text { Not } \\
\text { significant }\end{array}$ \\
\hline $\begin{array}{l}\text { DPK against LB through } \\
\text { Pend.BH }\end{array}$ & 1,077 & 1.67303 & $\begin{array}{l}\text { Not } \\
\text { significant }\end{array}$ \\
\hline $\begin{array}{l}\text { Capital towards LB through } \\
\text { Pend.BH }\end{array}$ & 0880 & 1.67303 & $\begin{array}{l}\text { Not } \\
\text { significant }\end{array}$ \\
\hline
\end{tabular}

From the table above, it can be concluded that the value of $t$ arithmetic <from $t$ table so that the variables of revenue sharing, TPF and capital have no effect on net income through revenue sharing.

\section{Conclusion}

Based on the results of data analysis and the discussion described above, the following conclusions can be drawn:

The profit sharing variable has a positive effect on revenue sharing. Profit sharing financing that is managed properly is able to provide revenue sharing for the bank if the distribution of the financing in return runs smoothly. This research is in line with Muhammad Afif Darwis' research, that profit sharing financing has a positive and significant effect on revenue sharing.

TPF has no effect and is not significant for revenue sharing. DPK is one of the sources of bank funds collected in the form of savings, current accounts and time deposits and will be distributed in the form of financing. TPF has no effect on revenue sharing because of the decrease in savings, current accounts and time deposits. The proof is that in BMI 2016 current accounts, savings and time deposits decreased by $-46.9 \%,-7.6 \%$ and $-6.01 \%$. At Bank Victoria Syariah in 2015, savings decreased by $-22.9 \%$, in 2016 it decreased by $-20.2 \%$. In 2016 current accounts decreased by $-98.5 \%$, in 2017 current accounts were worth 0 . In 2017 time deposits amounted to $-2.71 \%$. In 2019 , current accounts decreased by $93.1 \%$ and savings decreased by $-7.65 \%$. In 2015 and 2016, 2017, and 2018 BRIS demand deposits were valued at 0. At Bank Jabar Banten Syariah in 2018 current accounts fell -18.2\%, deposits also fell 18.8\%. At Bank Mega Syariah 2015, 2016, and 2017 the current account is 0. At Bank Panin 
Dubai Syariah, giro is worth 0. Another reason DPK does not affect revenue sharing is because of the risk of displacement caused by customers moving their funds which is driven by the real profit sharing rate that is lower than the interest rate. Islamic banks must be more careful in managing the financing for these results.

Capital has a negative and significant effect on revenue sharing. A negative sign indicates the relationship is reversing. If there is a lot of capital, the channeled financing is small and the profit sharing income obtained is also small. The amount of capital owned by the bank is not balanced with the amount of financing channeled by the bank, resulting in idle funds. Unemployed funds can be seen from the Financing Depsit Ratio (FDR). Whereat BMI in 2014 the FDR was $84.14 \%$, in $2017,84.41 \%, 2018$ was $73.18 \%$. In 2015 BRIS, FDR was 84.16\%, $201681.42 \%, 2017$ FDR was $71.87 \%$ and in 2018 FDR was 75.49\%. In 2014 BSM the FDR was 81.92\%, 2015 FDR was 81.99\%, $201679.19 \%$, 2017 FDR was 77.6\%, 2018 FDR was $77.25 \%$. In the 2016 BNIS, the FDR was $84.57 \%$, in 2017 the FDR was $80.21 \%$, in 2018 the FDR was $79.62 \%$. The standard used by Bank Indoonesia for FDR is $80 \%$. The lower the FDR, the less effective the bank is in channeling TPF and capital collected by Islamic banks.

Profit sharing financing has no effect on net income because the growth of mudharabah financing at BMI in 2016 fell by $27.7 \%$. In 2016 mudharabah financing at Bank Jabar Banten Syariah decreased -30.6\%. In 2018 BRI Syariah mudharabah financing fell -43.5\%. At Panin Dubai Syariah Bank in 2016 it fell -42.4\%. At Bank Mega Syariah 2016, 2018, and 2019 mudharabah financing was worth 0. In 2016 at Bank Syariah Bukopin mudharabah financing decreased by $-14.8 \%$, in 2018 mudharabah financing decreased by $-41.2 \%$

Another reason for profit sharing financing has no effect on net income is due to nonperforming financing as seen from the Net Performing Financing (NPF) ratio. Bank Indonesia sets a maximum NPF rate of 5\%. The NPF BMI was 7.11\%. At Bank Victoria Syariah in 2016 the NPF was 7.21\%. In the 2017 and 2018 BRIS, the NPF was $6.43 \%$ and 6.73\%. At Bank Jabar Banten Syariah in 2015, 2016, 2017 the NPF was 6.93\%, 17.91\%, and 22.04\%. In BSM 2015 NPF 6.06\%. At Panin Dubai Syariah Bank 2017 NPF 12.52\%. At Bank Syariah Bukopin NPF in 2017 and 2018 amounted to $7.85 \%$ and 5.71\%.

TPF variable has a positive and significant effect on net income. The more TPF that is channeled in the form of financing, the TPF will have an effect on increasing profits. The more the amount of funds raised, the more the amount of funds channeled will also be raised. This means that the more funds collected, the bank can provide a lot of financing. From this financing, income will be obtained and will increase bank profits.

The variable of capital has no and insignificant effect on net income.The amount of capital owned by the bank is not balanced in providing profit sharing financing, so that the profit sharing received from profit sharing financing is not balanced with the profit sharing that must be given to customers who own capital, in the end this will affect the decline in profits that will be obtained by the bank. Capital has no effect on net income, also because Islamic banking financing is still dominated by murabahah financing. Comparison of murabahah financing and profit sharing financing can be seen in OJK publications. In 2017 BRIS murabahah financing was Rp. 15,083,878,000,000, and in 2018 Rp. $16,008,953,000,000$ while the financing for the 2017 results was Rp. 6,435. 239,000,000 and in 2018 amounting to Rp. 8,232,976,000,000 In 2017 BSM murabahah financing was Rp. $54,783,980,000,000$ and 2018 Rp. 57,782,020,000. 000 while the financing for the results of 2017 is Rp. 21,038,964,000,000 and 2018 Rp. 23,978,566,000,000. At BMI 2017 murabahah financing was Rp. 27,016,195,000,000 and 2018 amounting to Rp. 21,618,823 and profit sharing financing in 2017 of Rp. 20,595,108,000,000 and 2018 of Rp. 16,981,461,000,000. Likewise with other Islamic Commercial Banks where murabahah financing is more dominant than profit-sharing financing 
Profit sharing variable has no effect and is not significant to net income.Profit sharing income has no effect on net income because the profit sharing income from mudharabah financing in 2016 at BMI fell by $-54.5 \%$, Musyarakah revenue sharing in 2016 fell by 19.9\%. In 2015 the mudharabah financing on BVS decreased by $-67.4 \%$, in 2018 the mudharabah financing on the BVS decreased by $-11.6 \%$. In 2018 mudharabah financing at BRIS decreased by $-43.5 \%$. In 2017, the BJBS mudharabah financing fell by $-30.2 \%$, then in 2018 the musharaka financing fell by $-18.9 \%$. In 2017, BNIS mudharabah financing decreased by $-25.8 \%$. In 2017, BSM mudharabah financing decreased by $-7.89 \%$. In the 2016 to 2019 BMGS, the mudharabah profit sharing income is worth 0. This means that in 2016, 2017, 2018 and 2019 BMGS does not receive revenue sharing. Likewise, in 2017 the mudharabah profit sharing income decreased by $-6.66 \%$. In 2018, the BPDS mudharabah profit-sharing income fell by $-60.6 \%$. In 2017 in BSB, the mudharabah profit sharing income fell by $-57.3 \%$ and in 2018 the musyarakah profit sharing income fell by $-41.1 \%$.

\section{References}

Anshori, Ghofur Abdul, Perbankan Syariah di Indonesia. Yogyakarta: Gajah Mada University Press, 2018.

Ascarya dan Diana Yumanita, Bank Syariah, Gambaran Umum. Jakarta: Pusat Pendidikan dan Studi Kebanksentralan (PPSKA) Bank Indonesia, 2005.

Dianto, E. et al. (2020). BNI Marketing Strategy for Credit Cards in Dealing Global Competition in State Bank Indonesia (Persero) Tbk Banda Aceh Branch Office. Budapest International Research and Critics Institute-Journal (BIRCI-Journal Vol 3 (2): 1134-1146.

Ikit, Manajemen Dana Bank Syariah, Yogakarta: Gava Media, 2018.

Indah Wahyuningsih, Pengaruh Pendapatan Pembiayaan Mudharabah Terhadap Profitabilitas (ROA), Vol. 2, No. 2. Jurnal Economic, 2017.

Ismail, Perbankan Syariah. Jakarta: Kencana, 2011.

Kasmir, Bank dan Lembaga Keuangan Lainnya. Jakarta: RajaGrafindo Persada, 2014.

Muhammad, Manajemen Dana Bank Syariah. Jakarta: RajaGrafindo Persada, 2014.

Muhammad Afif Darwis, Pengaruh Pembiayaan Mudharabah dan Musyarakah Terhadap Laba Bersih Melalui Pendapatan Bagi Hasil Pada Bank Umum Syariah. Tesis Alauddin Makassar. 2016.

Rahmati, A., Mulyadi, D., and Januddin. (2018). Analysis of Low Realization For Mudharabah Financing at Muamalat Indonesia Bank, Banda Aceh. Budapest International Research and Critics Institute-Journal (BIRCI-Journal) Vol I (4): 215-223.

Soemarsono, Akuntansi Suatu Pengantar, Buku1, Edisi Lima. Jakarta: Salemba Empat 2002.

Yani Suryani dan Desi Ika, Faktor-faktor yang Mempengaruhi Pertumbuhan Laba Bank Umum Syariah di Indonesia. Jurnal Akuntansi dan Bisnis. ISSN. 2443-3071, 2019. 